\title{
Mutation screening of two candidate genes from $13 q 32$ in families affected with Bipolar disorder: human peptide transporter (SLCI 5AI) and human glypican5 (GPC5)
}

\author{
Manjula Maheshwari ${ }^{1}$, SL Christian ${ }^{2}, \mathrm{C} \mathrm{Liu}^{2}$, JA Badner ${ }^{2}$, S Detera- \\ Wadleigh $^{3}$, ES Gershon ${ }^{2}$ and Richard A Gibbs*1
}

\begin{abstract}
Address: ${ }^{1}$ Department of Molecular \& Human Genetics, Human Genome Sequencing Center, One Baylor Plaza, N1519 Houston, TX 77030, USA ${ }^{2}$ Department of Psychiatry, University of Chicago, Chicago, IL 60637, USA and ${ }^{3}$ National Institute of Mental Health Intramural Research Program, National Institutes of Health, Bethesda, MD 20892-4094, USA

Email: Manjula Maheshwari - manjulam@bcm.tmc.edu; SL Christian - schrist@yoda.bsd.uchicago.edu; C Liu - cliu@yoda.bsd.uchicago.edu; JA Badner - jbadner@psy-138-006.bsd.uchicago.edu; S Detera-Wadleigh - DeteraS@intra.nimh.nih.gov;

ES Gershon - egershon@yoda.bsd.uchicago.edu; Richard A Gibbs* - agibbs@bcm.tmc.edu

* Corresponding author
\end{abstract}

Published: 22 October 2002

BMC Genomics 2002, 3:30

This article is available from: http://www.biomedcentral.com/I47I-2/64/3/30

(c) 2002 Maheshwari et al; licensee BioMed Central Ltd. This is an Open Access article: verbatim copying and redistribution of this article are permitted in all media for any purpose, provided this notice is preserved along with the article's original URL.

\begin{abstract}
Background: Multiple candidate regions as sites for Schizophrenia and Bipolar susceptibility genes have been reported, suggesting heterogeneity of susceptibility genes or oligogenic inheritance. Linkage analysis has suggested chromosome I $3 q 32$ as one of the regions with evidence of linkage to Schizophrenia and, separately, to Bipolar disorder (BP). SLCI5AI and GPC5 are two of the candidate genes within an approximately 10-cM region of linkage on chromosome 13q32. In order to identify a possible role for these candidates as susceptibility genes, we performed mutation screening on the coding regions of these two genes in 7 families $(n-20)$ affected with Bipolar disorder showing linkage to $13 q 32$.
\end{abstract}

Results: Genomic organization revealed 23 exons in SLCI5AI and 8 exons in GPC5 gene respectively. Sequencing of the exons did not reveal mutations in the GPC5 gene in the 7 families affected with BP. Two polymorphic variants were discovered in the SLCI5AI gene. One was T to $C$ substitution in the third position of codon encoding alanine at I 403 position of mRNA in exon 17 , and the other was $A$ to $G$ substitution in the untranslated region at position 2242 of mRNA in exon 23 .

Conclusions: Mutation analysis of 2 candidate genes for Bipolar disorder on chromosome 13q32 did not identify any potentially causative mutations within the coding regions or splice junctions of the SLCI5AI or GPC5 genes in 7 families showing linkage to 13q32. Further studies of the regulatory regions are needed to completely exclude these genes as causative for Bipolar disorder.

\section{Background}

Schizophrenia and associated mental illness are complex psychiatric disorders each affecting about $1 \%$ of the world population. Genetic evaluation of Schizophrenia and associated mental illness have suggested an important role for genetic factors [1-4], however, no specific gene or bi- 
ological marker has yet been identified. Genome scans have mapped several loci in various ethnic groups. Replications of these scans were positive in some cases and negative in others $[2,5,6]$. These data as well as reports of the specific candidate genes beginning to be identified implicate genetic heterogeneity of susceptibility genes $[7,8]$ and also sex specific differences [9] in the molecular basis of disease phenotype. Linkage analyses of all published genome scans, for Schizophrenia genes, have identified chromosome $13 \mathrm{q} 32$ as one of the regions with evidence of linkage to Schizophrenia. In independent genome scans, Bipolar disorder has also shown linkage to this region [10-13]. The linkage region for both disorders spans approximately $10 \mathrm{cM}$ on chromosome 13q32-q33 [14]. The region between D13 S71 and D13S274 showed linkage to Bipolar disorder based on a whole genome scan with an average marker spacing of $\sim 6 \mathrm{cM}$ on $13 \mathrm{q} 32$. Fine mapping of this region, using nine additional markers, with an average spacing of $0.9 \mathrm{cM}$ confirms the evidence of linkage to 13q32 around markers D13S79-D13S225 [15]. Association analyses with GASSOC TDT and ASPEX /Sib_tdt showed linkage disequilibrium signals with several markers, including D13S280 which need follow up by typing more markers in the region in a larger sample size [15]. Meta analysis of whole-genome linkage scans further strengthens the susceptibility locus of BP on chromosome 13q32 [13]. All these studies clearly point towards further efforts in the identification of susceptibility genes for this disorder. Based on evidence of linkage, a comprehensive linkage map was developed around this region [14]. Complete annotation of this region may include as many as 200 genes. One approach to identify susceptibility locus is to use the candidate gene approach. Studies are underway at our center to identify susceptibility variants by mutation screening of candidate genes in this region on a small series of Bipolar families showing linkage to $13 \mathrm{q} 32$. For the present study we have selected two candidate genes viz. human peptide transporter (SLC15A1) and human glypican5 (GPC5) for mutation screening from this region.

SLC15A1 is an intestinal oligopeptide transporter also referred to as HPEPT1 that belongs to solute carrier family15. It is expressed in intestine, kidney, liver and brain [16]. The function of SLC15A1 is to absorb and transport small peptides $[17,18]$. The efficiency of absorption and transportation of L DOPA and its metabolite dopamine, which are neurotransmitter candidates, is increased by SLC15A1 [19]. Therefore, it is an important potential gene for future drug design, delivery, and targeting [20].

GPC5 belongs to the cell surface heparan sulfate proteoglycan family and is expressed in limb, kidney, developing central nervous system and brain tissue $[21,22]$. In vertebrates 6 glypican family members belonging to the proteoglycan family have so far been characterized [23]. Although there is a high degree of conservation of polypeptide sequence among family members, they are localized to different chromosomes. Glypican 5 is structurally correlated to glypican 3 and localized to chromosome 13q32. Deletion of the $13 \mathrm{q}$ region is associated with human 13q syndrome, a developmental disorder [24]. Some of the proteoglycans play important functional roles in neurogenesis, axon guidance, synapse development [25], and cellular growth and differentiation $[26,27,23]$. Mutations in GPC3 cause Simpson-Golabi-Behmel syndrome $[28,29]$, however, no mutations were detected in the GPC5 and GPC6 genes [30]. The glypican1 gene has been suggested to be a good candidate for brachydactyly type $\mathrm{E}$ [31]. Given that, GPC5 is highly expressed in brain and mutations in other genes of the glypican families are associated with developmental disorder; GPC5 could be a potential candidate gene for Bipolar disorder.

In order to identify a possible role for these candidates (SLC15A1 \& GPC5) as susceptibility genes, we performed mutation screening of the coding regions in 7 families ( $\mathrm{n}$ $=20$ ) affected with Bipolar disorder showing linkage to 13q32. First, the accurate gene structure of SLC15A1 \& GPC5 was defined by analysis of the available draft human genomic sequence. Next, PCR primers and conditions for amplification and sequencing of each exon were developed and sequencing was performed.

\section{Results \\ Genomic structure}

We determined genomic structure of both the genes by aligning cDNA sequences with available human draft genomic sequences http://www.ncbi.nlm.nih.gov/. The entire SLC15A1 gene was represented in one BAC clone sequence AL357553 and GPC5 in 6 BAC clone sequences. Alignment of SLC15A1 cDNA sequence (accession number U21936) with the genomic sequence (accession no. AL357553) revealed that it is a large gene with a coding sequence of $3105 \mathrm{bp}$ long, having 23 exons spread over $\sim 68.85 \mathrm{~kb}$ of genomic sequence. The splice junctions follow the GT/AG rule (Table 1).

Alignment of GPC5 cDNA (accession number U66033) with the working draft sequence revealed a genomic organization of 8 exons, which was represented in 6 BAC clone sequences. The coding sequence of GPC5 gene is 2558 bp long and encodes 572 amino acids. The first two exons of the GPC5 gene are present in BAC clone accession number AL138714, exons 3,4,5 in AC027429, exon 6 in AL162456, exon 7 in AL163537 and exon 8 in AL157363 (Table 2). Most of the splice junctions follow the GT/AG rule. 
Table I: Genomic structure of human peptide transporter (SLCI5AI) showingnumber of exons, cDNA position, exon size, exon-intron junctions, 3' \& 5' intron acceptor \& donor sites, intron size and intron phase.

\begin{tabular}{|c|c|c|c|c|c|}
\hline \multirow[t]{2}{*}{ Exon } & \multirow{2}{*}{$\begin{array}{l}\text { cDNA bp } \\
\text { Position }\end{array}$} & \multirow[t]{2}{*}{ Exon Size } & Intron-Exon Junctions & \multirow[t]{2}{*}{ Intron Size bp } & \multirow[t]{2}{*}{ Intron Phase } \\
\hline & & & Intron 3' & & \\
\hline $\mathbf{I}$ & $2-61$ & 61 & CACCTG...CCATGGgtacgctc & $>25 \mathrm{~kb}$ & $\mathbf{I}$ \\
\hline 2 & $61-77$ & 16 & tcttttagGAATGTTCACACgtgagtac & 394 & 2 \\
\hline 3 & $78-159$ & 81 & tgtcgaAGTTTCTTT...TGCGAGgtaactgta & 102 & $\mathbf{I}$ \\
\hline 4 & $158-302$ & 144 & tgcaaaagCAATCC...GTTCAAgtgagtgc & 2091 & 2 \\
\hline 5 & $302-422$ & 120 & aaacacagGACCAT..GCACGTgtgagttg & 2008 & 2 \\
\hline 6 & $422-522$ & 100 & tttcccagGGTGCT...GGCCAGgtaagggt & 215 & 0 \\
\hline 7 & $519-611$ & 92 & cattgcagGAGAAA...TCAGAGgtaagaga & 2173 & 2 \\
\hline 8 & $611-696$ & 85 & ctccccagTTCAAC...CCCTGAgtaagtgg & 3277 & I \\
\hline 9 & 697-779 & 82 & ctatctagTTGTGT.....ATCGGTgtaagtat & 3294 & 0 \\
\hline 10 & $780-867$ & 87 & ttccttcagTTTGCC...TACGATgtaagtaac & 554 & 0 \\
\hline II & $867-957$ & 90 & aactacagGAGCGG...CAGCAGgtaatgtg & 1940 & $\mathbf{0}$ \\
\hline 12 & $955-1002$ & 47 & atttttaagGGCTCC...GAAATCgtaagtttg & 92 & 0 \\
\hline 13 & $1002-1034$ & 32 & tctttttagGGAGCTATGCAGgtagaagac & 77 & $\mathbf{0}$ \\
\hline 14 & $1030-1123$ & 93 & cctctgcagACCGTG...TTTCAC gtaggttga & 801 & 2 \\
\hline 15 & $1 / 20-1205$ & 85 & tgccatcagCTCCTT...ATCGATgtgagttgt & 2433 & 0 \\
\hline 16 & $1206-1325$ & 119 & tttgctcagAAAACT...TCTCAAgtaagtaga & 1699 & $\mathbf{0}$ \\
\hline 17 & $1326-1476$ & 150 & ctctatagACAAAT...CAGGTGgtaagtgtg & 1755 & 2 \\
\hline 18 & $1472-1522$ & 50 & tctctcagGTAAAG...AATCAGgtatgtata & $>13 \mathbf{k b}$ & 2 \\
\hline 19 & $1519-1630$ & III & tgtttcagATTTGT.....TGGCATgtaagtac & 114 & 2 \\
\hline 20 & $1631-1739$ & 108 & tttgatagAAAAGG...AGGAAGgttagtaa & 522 & 0 \\
\hline 21 & $1738-1884$ & 146 & tgctgcagAATGAC....TCTCAGgtttcttg & 1279 & 0 \\
\hline 22 & $|879-199|$ & 112 & ttcctcagGCTCCT...AAACAGgtatggcg & 1273 & 0 \\
\hline 23 & $1990-3105$ & 1115 & cttcaaagTGGGCC...CTGTTCTTA & & \\
\hline
\end{tabular}

\section{Mutation analysis}

No mutations were identified in the GPC5 gene in the 7 families affected with Bipolar disorder. Two polymorphic variants were discovered in SLC15A1 gene, one in exon 17 and another one in exon 23. Sequence analysis revealed a $\mathrm{T}$ to $\mathrm{C}$ (Figure 1A) substitution in third position of codon encoding alanine at 1403 position of mRNA and A to G (Figure 1B) substitution at position 2242 of mRNA. Of these, 6 individuals ( 3 affected and 3 normal) were homozygous CC (exon 17), 15 (11 affected and 4 normal) were heterozygous TC (exon 17) and three were heterozygous AG (exon 23).

\section{Discussion}

Gene mapping studies using microsatellite markers have identified chromosome $13 \mathrm{q} 32$ as one of the putative loci for Schizophrenia and Bipolar disorder [10-13,15]. To begin identification of a susceptibility gene for Bipolar disorder, we have screened two candidate genes, SLC15A1 and GPC5, on the basis of their genetic localization within the $10 \mathrm{cM}$ region of chromosome 13q32 [14]. The entire SLC15A1 gene was represented in one BAC clone sequence AL357553 and GPC5 in 6 BAC clone sequences. Alignment of SLC15A1 cDNA sequence with genomic sequence (accession no. AL357553) revealed that it is a large gene with a coding sequence of 3105 bp long, having 23 exons spread over $\sim 68.85 \mathrm{~kb}$ of genomic sequence. The splice junctions follow the GT/AG rule (Table 1). A wide variety of transporters are found in the intestine and several genetic disorders have been shown to result from deficient intestinal transporters [20]. SLC15A1 consists of 708 amino acids with putative 12 transmembrane domains and 2 putative protein kinase $\mathrm{C}$ phosphorylation sites. Exon-intron boundaries occur mostly in the loops connecting transmembrane segments [32] suggesting a modular gene structure reflecting the TMS-loop repeat units in SLC15A1. Computer modeling and site directed mutagenesis studies suggested a list of amino acids for the transport functional activities. Tyrosine (Y167) and histidyl residues (H57, H111 and H121) are two of these amino acids playing important roles in the function of transporters [33-36]. In our mutation screening of families with Bipolar disorder we did not find variants at these positions. However, we did identify two variants in the SLC15A1 gene, one in exon 17 and another one in exon 23. Sequence analysis revealed a $\mathrm{T}$ to $\mathrm{C}$ substitution in the third position of codon encoding alanine at 1403 position (exon 17) of mRNA. Of these, 6 individuals were homozygous CC (29\%) and 15 were heterozygous TC (71\%) (exon 17). However, there was no amino acid change. Substitution of $\mathrm{T}$ to $\mathrm{C}$ in normal members as well, suggests it is a polymorphic variant and not a pathogenic mu- 
Table 2: Genomic structure of human glypican5 (GPC5) showing number of exons, cDNA position, BAC clones representing genomic sequence, exon-intron junctions, 3' \& $5^{\prime}$ intron acceptor \& donor sites, intron phase and exon size.

\begin{tabular}{|c|c|c|c|c|c|}
\hline \multirow[t]{2}{*}{ Exon } & \multirow{2}{*}{$\begin{array}{l}\text { cDNA bp } \\
\text { position }\end{array}$} & \multirow[t]{2}{*}{ BAC clone } & Intron-Exon Junctions & \multirow[t]{2}{*}{ Intron phase } & \multirow[t]{2}{*}{ Exon size } \\
\hline & & & $\begin{array}{l}\text { Intron 3' } \\
\text { acceptor }\end{array}$ & & \\
\hline I & $1-178$ & ALI387/4 & GACGGC...GGGCAGgtaagggg & $\mathbf{I}$ & 177 \\
\hline 2 & $175-339$ & ALI387|4 & gtgttccagGACCTG..TTCAAGgtggatct & $\mathbf{I}$ & 164 \\
\hline 3 & $338-1044$ & AC027429 & tgttacagAAACCC...GAACAGgtaagtag & 0 & 706 \\
\hline 4 & $1033-1168$ & AC027429 & tttaaaagGTAAAT...AAGAAAgtaagaca & I & 135 \\
\hline 5 & $1169-1294$ & AC027429 & tcatttagAGAATT...AAAAAGgtatttta & 2 & 129 \\
\hline 6 & $|293-| 4 \mid 5$ & ALI 62456 & cttgctagTTATAC...GTTCAGgtaagtcc & 0 & 122 \\
\hline 7 & $1414-1576$ & ALI 63537 & acaattagTTGTTA...CAGACTgtaagtgt & I & 162 \\
\hline 8 & $1576-2526$ & ALI57363 & ctctacagGGATGCC...TGGTGG & & 950 \\
\hline
\end{tabular}

tation. In exon 23, the variation observed was an $A$ to $G$ substitution in the untranslated region at position 2242 of mRNA. Of these, eighteen were homozygous AA (86\%) and three were heterozygous AG (14\%). The variant in exon 17 was also found in the SNP database (NCBI SNP cluster ID rs1339067) although the population frequency was not reported. An association study of this variant in a large population will aid in understanding the potential role of the SLC15A1 gene in Bipolar disorder.

Alignment of the GPC5 cDNA with the working draft sequence revealed a genomic organization of 8 exons, which was represented in 6 BAC clone sequences (Table 2 ). The whole GPC5 gene is 2558 bp long and encodes 572 amino acids. The first two exons of the GPC5 gene are present in BAC clone accession number AL138714, exons 3,4,5 in AC027429, exon 6 in AL162456, exon 7 in AL163537 and exon 8 in AL157363 (Table 2). Most of the splice junctions follow the GT/AG rule. The exon structure was confirmed by comparing the cDNA with nucleotide contig NT_009866. While we finished screening this gene for mutations, its genomic structure was published and confirms the presence of 8 exons with exon/intron boundaries following the AG/GT rule with a size of approximately $2 \mathrm{Mb}$ [30]. No mutations or polymorphisms were identified in the GPC5 gene in the 7 families affected with Bipolar disorder decreasing the likelihood that this gene is involved in the etiology of Bipolar disorder. Several disorders have been reported due to mutations in glypican gene families [31,37] and interestingly due to deletion of region on chr.13 q32 [24,38]. It would be interesting to study the occurrence of Schizophrenia or other associated mental illnesses in individuals with these deletions. Mutation screening of the glypican genes in these patients might give clue to Schizophrenia susceptibility locus.

Absence of pathogenic mutations in the two genes GPC5 and SLC15A1 studied in seven families of Bipolar disorder
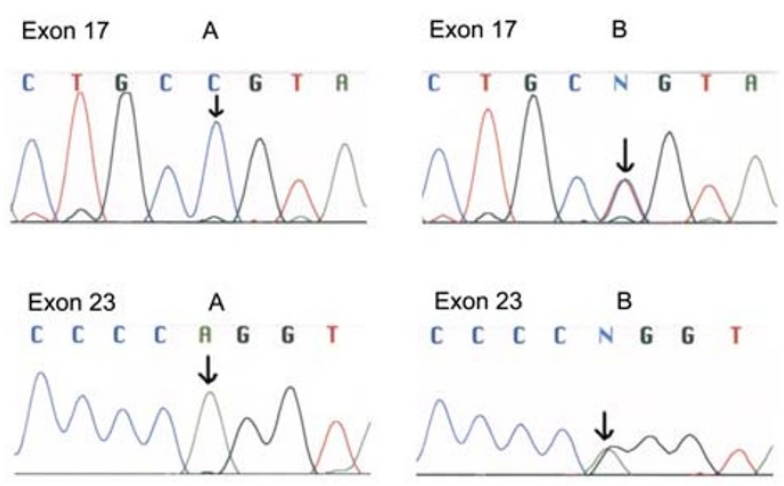

Figure I

Sequencing traces demonstrating polymorphic variants in exon $17(T \rightarrow C)$ and exon $23(A \rightarrow G)$ of SLCI5AI gene. Exon 17 A: Homozygous CC, Exon 17 B: Heterozygous TC, Exon 23 A: Homozygous AA, Exon 23 B: Heterozygous AG.

suggests that these genes are presumably not involved in the susceptibility locus for Bipolar disorder in the families screened. However, due to the complex nature of these diseases, no definite conclusions can be drawn. We cannot rule out genetic heterogeneity for these genes and suggest studying more families. For example, the NOTCH 4 gene that is located on chromosome 6p21.3 confers susceptibility to Schizophrenia in the British population but not in the Japanese population [39]. Genetic heterogeneity is very common in hereditary deafness [40]; also the prevalence of mutations in the connexin 26 gene is a major cause of non-syndromic autosomal recessive deafness that varies in different populations [41]. 
Table 3: Human peptide transporter (SLCI5AI) : PCR Primers and Annealing temperature

\begin{tabular}{|c|c|c|c|c|c|c|}
\hline Exon & cDNA bp & Position & $\begin{array}{l}\text { Forward Primer } \\
\text { Primer sequence } 5^{\prime} \rightarrow 3^{\prime}\end{array}$ & $\begin{array}{l}\text { Reverse Primer } \\
\text { Primer sequence } 5^{\prime} \rightarrow 3^{\prime}\end{array}$ & Product Size bp & $\begin{array}{l}\text { Annealing } \\
\text { Temp. }\end{array}$ \\
\hline 2 & $61-77$ & $\mathrm{PI7}$ & ccctctgaccaccctaaaaa & tgaacccttagggggtaaaaca & 191 & 60 \\
\hline 3 & $78-159$ & $\mathrm{PI}$ & tggggaaggattagtgtaggg & aactttcccagccacgagt & 498 & 60 \\
\hline 4 & $158-302$ & & & & & \\
\hline 5 & $302-422$ & $\mathrm{P} 2$ & tgtggtggagtcaaaagtgg & cctgaagacccagctcaatc & 356 & 60 \\
\hline 6 & $422-522$ & P3 & gtcactatgccaggeccact & gcctctgactcctggatgtg & 258 & 60 \\
\hline 7 & $519-611$ & $\mathrm{PI} 8$ & agtggattgatagccaaagtcatct & aagacacggacttggcctta & 200 & 60 \\
\hline 8 & $611-696$ & $\mathrm{P} 4$ & tgtgaaagcaatacgtaattatcag & ctactttttgttgccacttgttacat & 295 & 60 \\
\hline 9 & $697-779$ & $\mathrm{PI} 6$ & tcaagagccatttctattcttcc & gcatctctctaggccacagg & 350 & 48 \\
\hline 10 & $780-867$ & P5 & tgaaatgtgcttccctgaca & tcactgaccattttgtccatgt & 254 & 60 \\
\hline 11 & $867-957$ & P6 & acctcccagcttgcctcta & tgaagtgagccttggtacctg & 293 & 60 \\
\hline 12 & $955-1002$ & P7 & cagggtactgctttgtgcag & tatcctctaggcgaggttgc & 701 & 60 \\
\hline 13 & $1002-1034$ & & & & & \\
\hline 14 & $1030-1123$ & & & & & \\
\hline 15 & $1124-1205$ & P8 & aagatggggagaggtgcttt & gctccagggctcagtttaca & 348 & 60 \\
\hline 16 & $1206-1325$ & P9 & aggtctgtgattggcagctt & gctggccttggcatttatac & 379 & 60 \\
\hline 17 & $1326-1476$ & PIO & aaacctcatgacggtgtctg & ttttggcctccagtatcaca & 400 & 60 \\
\hline 18 & $1472-1522$ & PII & gcctccagagcccttctaat & tcagccagccttacattgct & 331 & 60 \\
\hline 19 & $1519-1630$ & $\mathrm{P} 12$ & gacattgtggcggaatctct & gggagtattgcccaacttca & 356 & 60 \\
\hline 20 & $1631-1739$ & & & & & \\
\hline 21 & |738-1884 & $\mathrm{P} 13$ & gtcccatcagcattttctgc & ggtcaaactcaatttacctgttcg & 292 & 60 \\
\hline 22 & |879-199| & $\mathrm{PI} 4$ & ccatgatgaccatgaacagg & cattgaggccacctgacttt & 299 & 60 \\
\hline 23 & $1993-2315$ & $\mathrm{PI5}$ & ccaagaacatgtacgcacca & aggctgaggcaggagaatta & 540 & 60 \\
\hline
\end{tabular}

Table 4: Human glypican5 (GPC5) : PCR Primers and Annealing temperature

\begin{tabular}{clllll}
\hline Exon & cDNA U66033 & Forward Primer 5' $\rightarrow \mathbf{3}^{\prime}$ & Reverse Primer 5' $\rightarrow$ 3' & Product Size & $\begin{array}{c}\text { Annealing } \\
\text { Temperature }\end{array}$ \\
\hline 1 & $1-178$ & cgctgtgtcttccacgtct & ctacccgcaccaagcatc & 410 & 60 (5\%DMSO) \\
2 & $175-339$ & gtgcaggactggtcataacg & gtttcccaatccaactcag & 455 & 60 \\
3 & $338-1044$ & agcagatggacggtgttagc & caagaagtcagactgaaaatgtg & 797 & 60 (DT) \\
4 & $1033-1168$ & gcataccacataaatgtccatga & ggcttactttctttctcttctgg & 408 & 60 \\
5 & $1169-1294$ & ttgatggcctttattgtgga & tcaggttttgttgttctttcc & 352 & 48 \\
6 & $1293-1415$ & gaggaaattccgacctcaaa & cactgcatattgactgcatcc & 401 & 60 \\
7 & $1414-1576$ & ccatttccaattctcttgc & tgtaagactttgcccgctatt & 466 & 60 \\
\hline
\end{tabular}

Considering the complex nature of the disease and the supportive evidence of linkage to chromosome $13 q 32$ $[13,15]$ it would be worth while to continue further studies to find out Schizophrenia susceptibility genes at this critical region. As the human genome reference sequence is nearing completion, the analysis of genetic variation is becoming important. Our plans are to annotate all the genes for a 10-mega base region on chromosome 13 and develop a high density SNP map. Aim is to identify variants in the critical region, to predict haplotypes from numerous variants observed and perform mutation analysis by direct sequencing with the ultimate objective of identifying specific sequence/haplotype associated with the disease phenotype.

\section{Methods}

\section{Study Subjects}

A total of 7 nuclear families (n-20) affected with Bipolar disorder were selected. The seven families consist of five normal parents, five affected parents, seven affected patients, one normal sib and two affected members. These families were selected from four known pedigree series with evidence of linkage to chromosome 13q32[15].

\section{Genomic structure determination}

The genomic structures of SLC15A1 (accession number U21936) and GPC5 (accession number U66033) were determined by direct comparison of their full-length cDNA with the sequence of human chromosome 13 genomic 
clones retrieved from the GenBank htgs database http:// www.ncbi.nlm.nih.gov/ by BLASTN searching. Intronic oligonucleotide primer pairs flanking the coding fragments were designed for both the genes using program primer 3 http://www.genome.wi.mit.edu/cgi-bin/primer/ primer3.cgi using the genomic sequences of SLC15A1 and GPC5 gene respectively.

\section{Mutation analysis}

Mutation screening of the coding region of the genes for sequence variants was performed by PCR amplification of 20 samples of 7 BP families and a control sample. Each sample was analyzed for exon 2-23 of the SLC15A1 gene (Table 3 ) and 7 coding fragments of the GPC5 gene (Table 4). Twenty two fragments of the SLC15A1 gene were amplified in eighteen reactions P1-P18 (Table 3). PCR reactions were carried out under the standard PCR conditions. In brief each 50-ul reaction contained $50 \mathrm{ng}$ of genomic DNA, 20 pmole of each primer, 1 unit of AmpliTaq Gold DNA polymerase, $5 \mathrm{ul}$ of $10 \mathrm{X}$ buffer, $2.5 \mathrm{ul}$ of $2.5 \mathrm{mM}$ of $\mathrm{MgCl} 2$ \& $2.5 \mathrm{mM}$ of dNTPs. Amplification conditions were $94^{\circ} \mathrm{C} / 12 \mathrm{~min}, 45$ cycles of $94^{\circ} \mathrm{C} / 30 \mathrm{~s}, 60^{\circ} \mathrm{C} / 30 \mathrm{~s}$, $70^{\circ} \mathrm{C} / 90 \mathrm{~s}$ followed by final extension step of $70^{\circ} \mathrm{C} / 5$ $\mathrm{min}$. Sequences of the primers and annealing temperature of each amplification are given in Tables 3 \&4. PCR products were analyzed using 2\% agarose gel electrophoresis and purified by 96 well Qia Quick PCR purification kit (Qiagen). Sequencing of each exon except exon 3 of GPC5 was performed using BODIPY dye primer chemistry [42] on an ABI 3700 DNA sequencer (Applied Biosystems, Foster City, CA, USA). Exon 3 of GPC 5 was sequenced with ABI Big Dye terminator chemistry. The obtained sequences were compared with the corresponding control gene sequences using SEQUENCHER software (Gene codes corporation, Ann Arbor, MI, USA).

\section{List of abbreviations}

Human peptide transporter: SLC15A1

\section{Human Glypican5: GPC5}

\section{Authors' contributions}

MM carried out mutation screening of the candidate genes and drafted the manuscript. SLC participated in the development of $\sim 15 \mathrm{Mb}$ map region on human chromosome 13q32. CYL \& Author 4, SD Participated in initial genotyping of the families. JAB did the statistical analysis to select the pedigrees. ESG and RAG are PI and CO PI of the project and participated in its design and coordination.

\section{Addendum}

While screening an additional three families, and reanalysis of our previous families we noted two variants in exon three: One was A155V (C>T) and second was R223C $(\mathrm{C}>\mathrm{T})$. Of the 23 subjects studied, 5 ( 3 affected and 2 nor- mal) were heterozygous Ala/Val. 1 (affected) homozygous $\mathrm{Val} / \mathrm{Val}$ and 17 (13 affected and 4 normal) were homozygous Ala/Ala. The second variant R223C was observed in 2 ( 1 affected and 1 normal) subjects, both were heterozygous Arg/Cys, 16 affected and 5 normal subjects were homozygous Arg/Arg and none were Cys/Cys homozygous. An association study of the variants detected in GPC5 and SLC15A1 genes in a large gene population will aid in understanding the potential role of these genes in Bipolar disorders.

\section{Acknowledgements}

This work was supported by a grant from I R0I MH65560-0I.

\section{References}

I. Levinson DF, Holmans P, Straub RE, Owen MJ, Wildenauer DB, Gejman PV, Pulver AE, Laurent C, Kendler KS, Walsh D, Norton N, Williams NM, Schwab SG, Lerer B, Mowry BJ, Sanders AR, Antonarakis SE, Blouin JL, DeLeuze JF and Mallet J Multicenter linkage study of Schizophrenia candidate regions on chromosomes $5 q, 6 q$, $10 \mathrm{p}$, and I3q: Schizophrenia linkage collaborative group III. Am J Hum Genet 2000, 67:652-663

2. Riley BP and McGuffin P Linkage and associated studies of Schizophrenia. Am J Med Genet 2000, 97:23-44

3. Baron M Genetics of Schizophrenia and the New Millenium: Progress and Pitfalls. Am J Med Genet 200I, 68:299-3I 2

4. Gurling $H$, Kalsi G, Brynjolfson J, Sigmundsson T, Sherrington R, Mankoo B, Read T, Murphy PBE, McQuillin A, Petursson H and Curtis $D$ Genomewide genetic linkage analysis confirms the presence of susceptibility loci for Schizophrenia, on chromosomes Iq32.2, 5q33.2, and 8q2 I-22 and provides support for linkage to Schizophrenia, on chromosomes I Iq23.3-24 and 20q I2. I-I I.23. Am J Hum Genet 200I, 68:66I-673

5. Thaker $\mathrm{G}$ and Carpenter JW Advances in Schizophrenia. Nature Medicine 2001, 7:667-67I

6. Waterworth DM, Bassett AS and Brzustowicz LM Recent advances in the genetics of Schizophrenia. CMLS 2002, 59:33I-348

7. Williams J, Spurlock G, Holmans P, Mant R, Murphy K, Jones Lea, Cardno A, Asherson P, Blackwood D, Muir W, Meszaros K, Aschauer $\mathrm{H}$ and al MJe A meta-analysis and transmission disequilibrium study of association between the dopamine D3 receptor gene and Schizophrenia. Mol Psychiatry I998, 3: I4I-I49

8. Dubertret C, Gorwood P, Ades J, Feingold J, Schwartz JC and Sokoloff P Meta-analysis of DRD3 gene and Schizophrenia: ethnic heterogeneity and significant association in Caucasians. Am J Med Genet 1998, 81:318-322

9. Zubenko G, Hughes H, Stiffler J, Zubenko W and BB K Genome survey for susceptibility loci for recurrent, early-onset major depression: Results at 10 cM resolution. Am J Med Genet 2002, | | 4:4 | 3-422

10. Blouin JL, Dombroski BA, Nath SK, Lasseter VK, Wolyniec PS, Nestadt G, Thornquist M, Ullrich G, McGrath J, Kasch L, Lamacz M, Thomas MG, Gehrig C, Radhakrishna U, Snyder SE, Balk KG, Neufeld K, Swartz KL, DeMarchi N, Papadimitriou GN, Dikeos DG, Stefanis CN, Chakravarti A, Childs B and Pulver AE Schizophrenia susceptibility loci on chromosomes I3q32 and 8p2I. Nat Genet 1998, 20:70-73

II. Brzustowicz LM, Honer WG, Chow EW, Little D, Hogan J, Hodgkinson $K$ and Bassett AS Linkage of familial Schizophrenia to chromosome 13q32. Am J Hum Genet 1999, 65:1096-I 103

12. Detera-Wadleigh SD, Badner JA, Berrettini WH, Yoshikawa T, Goldin LR, Turner G, Rollins DY, Moses T, Sanders AR, Karkera JD, Esterling LE, Zeng J, Ferraro TN, Guroff J], Kazuba D, Maxwell ME, Nurnberger JI Jr and Gershon ES A high-density genome scan detects evidence for a Bipolar-disorder susceptibility locus on I 3 q32 and other potential loci on I q32 and I 8p I I.2. Proc Nat Acad Sci U S A 1999, 96:5604-5609

13. Badner JA and Gershon ES Meta analysis of whole-genome linkage scans of Bipolar disorder and Schizophrenia. Mol Psychiatry 2002, 7:405-4II 
14. Chrisitan S, McDonough J, Liu C-y, Shaikh S, Vlamakis V, Badner J, Chakravarti $A$ and Gershon $E$ An evaluation of the assembly of an approximately I5-Mb region on human chromosome I 3q32-q33 linked to Bipolar disorder and Schizophrenia. Genomics 2002, 79:635-656

15. Liu C, Badner JA, SL C, Guroff J], Detera-Wadleigh SD and Gershon ES Fine Mapping Supports Previous Linkage Evidence for a Bipolar Disorder Susceptibility Locus on I3q32. Am J Med Genet 200I, 105:375-380

16. Fei YJ, Kanai Y, Nussberger S, Ganapathy V, Leibach FH, Romero MF, Singh SK, Boron WF and Hediger MA Expression cloning of a mammalian proton-coupled oligopeptide transporter. Nature 1994, 368:563-566

17. Liang R, Fei $Y$, Prasad P, Ramamoorthy S, Han H, Yang-Feng T, Hediger $M$, Ganapathy $V$ and Leibach $F$ Human intestinal $\mathbf{H}(+) /$ peptide cotransporter: cloning, functional expression, and chromosomal localization. J Biol Chem 1995, 20:6456-6463

18. Adibi SA The oligopeptide transporter (Pept-I) in human intestine: biology and function. Gastroenterology 1997, I I 3:332-340

19. Tamai I, Nakanihsi T, Nakahara H, Sai Y, Ganapathy V and Leibach F Improvement of L-do-pa absorption by dipeptidyl derivation, utilizing peptide transporter PepTI. J Pharm Sci 1998 87: I542-I546

20. Oh D, Han $\mathrm{H}$ and Amidon $\mathrm{G}$ Drug transport and targeting. Intestinal transport. Pharm Biotechnol 1999, I 2:59-88

2I. Veugelers M, Vermeesch J, Reekmans G, Steinfeld R, Marynen P and David G Characterization of glypican-5 and chromosomal localization of human GPC5, a new member of the Glypican gene family. Genomics 1997, 40:24-30

22. Saunders S, Paine-Saunders S and Lander A Expression of the cell surface proteoglycan glypican-5 is developmentally regulated in kidney, limb, and brain. Dev Biol 1997, 190:78-93

23. Paine-Saunders S, Viviano B and Saunders S GPC6, a novel member of the glypican gene family, encodes a product structurally related to GPC4 and is colocalized with GPC5 on human chromosome 13. Genomics 1999, 57:455-458

24. Brown S, Russo J, Chitayat D and Warburton D The I3q- syndrome: the molecular definition of a critical deletion region in band I 3q32. Am J Hum Genet 1995, 57:859-866

25. Yamaguchi $Y$ Heparan sulfate proteoglycans in the nervous system: their div roles in neurogenesis, axon guidance, and synaptogenesis. Semin Cell Dev Biol 200I, I 2:99-106

26. Nakato $\mathrm{H}$, Futch $\mathrm{T}$ and Selleck $\mathrm{S}$ The division abnormally delayed (dally) gene: A putative integral membrane proteoglycan required for cell division patterning during postembryonic development of the nervous system in Drosophila. Development 1995, I $21: 3687-3702$

27. Gonzalez A, Kaya M, Shi W, Song $\mathrm{H}$, Testa J, Penn L and Filmus $\mathbf{~ O C l}$ $5 / G P C 3$, a glypican encoded by a gene that is mutated in the Simpson-Golabi-Behmel overgrowth syndrome, induces apoptosis in a cell line-specific manner. J Cell Biol I998, I 4 I: I407$14 \mid 4$

28. Veugelers M, Cat B, Muyldermans S, Reekmans G, Delande N, Frints $\mathrm{S}$, Legius E, Fryns J, Schrander-Stumpel C, Weidle B, Magdalena N and David G Mutational analysis of the GPC3/GPC4 glypican gene cluster on Xq26 in patients with Simpson-Golabi-Behmel syndrome: identification of loss-of-function mutations in the GPC3 gene. Hum Mol Genet 2000, 9: I32।-1328

29. Li M, Shuman C, Fei Y, Cutiongco E, Bender H, Stevens C, WilkinsHaug L, Day-Salvatore D, Yong S, Geraghty M, Squire J and Weksberg R GPC3 mutation analysis in a spectrum of patients with overgrowth expands the phenotype of Simpson-Golabi-Behmel syndrome. Am J Med Genet 200I, 102:16I-168

30. Veugelers M, De Cat B, Delande N, Esselens C, Bonk I, Vermeesch J Marynen P, Fryns J and David G A 4-Mb BAC/PAC contig and complete genomic structure of the GPC5/GPC6 gene cluster on chromosome 13q32. Matrix Biol 200I, 20:375-385

3I. Syrrou M, Keymolen K, Devriendt K, Holvoet M, Reinhilde T, Verhofstadt $K$ and Fryns J-P Glypican I gene: Good candidate for brachydactyly type E. Am J med Genet 2002, 108:310-3/4

32. Uttri A, Johns S and Sadee W Genomic Structure of ProtonCoupled Oligopeptide Transporter SLCI5AI and pH-Sensing regulatory Splice Variant. AAPS PharmSci 200I, 3:E6

33. Bolger M, Haworth I, Yeung A, Ann D, Grafenstein H, Alvarez S, Okamoto C, Kim K, Basu S, Wu S and Lee V Structure, Function, and Molecular Modeling Approaches to teh Study ofthe In- tenstinal Dipeptide Tranporter PepTI. I Pharm Sci 1998, 87:|286-|29|

34. Yeung A, Basu S, Wu S, Chu C, Okamoto C, Alvarez S, Grafenstein H, Shen W, Kim K, Bolger M, Haworth I, Ann D and Lee V Molecular Identification of a Role for Tyrosine 167 in the Function of the Human Intestinal Proton-Coupled Dipeptide transporter (SLCI5AI). Biochem Biophys Res Commum 1998, 250:103107

35. Lee V, Chu C, Mahlin E, Basu S, Ann D, Bolger M, Haworth I, Yeung A, Wu S, Alvarez $S$ and Okamoto $C$ Biopharmaceutics of Transmucosal Peptide and Protein Drug Administration: Role of Transport Mechanisms with a Focul on the Involvement of PepTI.J Controlled Rel 1999, 62:129-140

36. Chen $X$, Steel $A$ and Hediger MA Functional Roles of Histidine and Tyrosine Residues in the $\mathrm{H}(+)$-Peptide Transporter PepTI. Biochem Biophys REs Commum 2000, 272:726-730

37. Li M, Squire J and Weksberg R Molecular genetics of Wiedemann-Beckwith syndrome. Am J Med Genet 1998, 79:253-259

38. Shanske A, Ferreira J, Leonard J, Fuller P and Marion R Hirschsprung disease in an infant with a contiguous gene syndrome of chromosome I3. Am J Med Genet 200I, I02:23I-236

39. Ujike H, Takehisa Y, Takaki M, Tanaka Y, Nakata K, Takeda T, Kodama M, Fujiwara Y, Yamamoto A and Kuroda S NOTCH4 gene polymorphism and susceptibility to Schizophrenia and schizoaffective disorder. Neurosci Lett 200I, 30 I:4I-44

40. Van Camp G, Willems $P$ and Smith R Nonsyndromic hearing impairment: unparalleled heterogeneity. Am J Hum Genet I997, 60:758-764

4I. Rabionet R, Zelante L, Lopez-Bigas N, D'Agruma L, Melchionda S, Restagno G, Arbones M, Gasparini P and Estivill X Molecular basis of childhood deafness resulting from mutations in the GJB2 (connexin 26) gene. Hum Genet 2000, 106:40-44

42. Muzny DM, Metzker M, Bouck J, Gorrell J, Ding Y, Maxim E and Gibbs $\mathrm{R}$ Using BODIPY dye-primer chemistry in large-scale sequencing. IEEE Engineering in Med Biol 1998, I 7(6):88-93

Publish with Biomed Central and every scientist can read your work free of charge

"BioMed Central will be the most significant development for disseminating the results of biomedical research in our lifetime. "

Sir Paul Nurse, Cancer Research UK

Your research papers will be:

- available free of charge to the entire biomedical community

- peer reviewed and published immediately upon acceptance

- cited in PubMed and archived on PubMed Central

- yours - you keep the copyright

Submit your manuscript here:

http://www.biomedcentral.com/info/publishing_adv.asp
BioMedcentral 